\title{
Table of Council Directives
}

Council Directive 64/221 (Derogations from the Free Movement)

Council Directive 68/630 on the rights of entry and residence

Council Directive 75/117/EEC Equal Pay Directive

Council Directive 75/129/EEC on the approximation of the laws of the Member States relating to collective redundancies (Collective Redundancies Directive)

Council Directive 76/207/EEC Equal Treatment Directive

Council Directive 77/187/EEC on the approximation of laws of the Member States relating to the safeguarding of employees' rights in the event of transfers of undertakings, businesses, or parts of businesses (Acquired Rights Directive)

Council Directive 78/855/EEC Third Council Directive concerning mergers of public limited companies

Council Directive 79/7/EEC on the progressive implementation of the principle of equal treatment for men and women in matters of social security

Council Directive 80/987/EEC on the approximation of laws of the Member States relating to the protection of employees in the event of the insolvency of their employer (Insolvency Directive)

Council Directive 86/378/EEC on equal treatment in occupational schemes of social security

Council Directive 86/613/EEC on equal treatment in respect of self-employed social security

Council Directive 89/391/EEC Framework Directive on health and safety

Council Directive 89/654/EEC on the minimum safety and health requirements for the workplace

Council Directive 89/655/EEC on the minimum health and safety requirements for the use of work equipment by workers

Council Directive $89 / 656 /$ EEC on the minimum health and safety requirements for the use by workers of personal protective equipment at the workplace

Council Directive 90/269/EEC on the minimum health and safety requirements for the manual handling of loads where there is a risk particularly of back injury to workers

Council Directive 90/270/EEC on minimum health and safety requirements for work with display screen equipment (VDUs) 
Council Directive 90/394/EEC on the protection of workers from the risks relating to exposure to carcinogens at work

Council Directive 90/679/EEC on the protection of workers from the risks related to exposure to biological agents at work

Council Directive 91/533/EEC on an employer's obligation to inform employees of the conditions applicable to the contract of employment relationship (Proof of Employment Directive)

Council Directive 92/56/EEC amending Council Directive 75/129/EEC on the approximation of the laws relating to collective redundancies (Collective Redundancies Directive)

Council Directive 92/57/EEC on the implementation of minimum health and safety requirements at temporary or mobile construction sites

Council Directive 92/58/EEC on the minimum requirements for the provision of safety and/or health signs at work

Council Directive 92/85/EEC on the introduction of measures to encourage improvements in the safety and health at work of pregnant workers and workers who have recently given birth or are breast feeding (10th) (Pregnant Workers' Directive)

Council Directive 93/104/EC Working Time Directive

Council Directive 94/33/EC Young Workers' Directive

Council Directive 94/45/EC European Works Councils Directive

Council Directive 95/46/EC on data protection

Council Directive 96/34/EC Parental Leave Directive

Council Directive 96/71/EC Posted Workers Directive

Council Directive 96/97/EC amending Council Directive 86/378/EEC

Council Directive 97/42/EC, amended by Council Directive 99/38/EC

Council Directive 97/74/EC amending Council Directive 94/45/EC on European works councils

Council Directive 97/80/EC Burden of Proof Directive

Council Directive 97/81/EC Part-time Work Directive

Council Directive 98/23/EC Directive on Part-time Work (extended to the UK)

Council Directive 98/50/EC amending Council Directive 77/187/EEC

Council Directive 99/63/EC concerning the Agreement on the Organisation of Working Time of Seafarers concluded by ECSA and FST

Council Directive 99/70/EC Fixed-term Work Directive

Council Directive 2000/78/EC establishing a general framework for equal treatment in employment and occupation

Council Directive 2001/86/EC Directive on Employee Involvement

Council Directive 2002/14/EC National Consultation and Information Directive 